\title{
Analysis of Integrated Science Process Skills and Problem-Solving Abilities Through Mini-Research Learning of Biology Students
}

\author{
Rahma Widiantie $^{1}$, Ina Setiawati ${ }^{2}$, Edi Junaedi ${ }^{3}$ \\ Biology Education Study Program, FKIP, Kuningan University \\ \{rahma.widiantie@uniku.ac.id\}
}

\begin{abstract}
This study aims to analyze how Mini Research learning can affect Integrated Science Process Skills (KPS) and problem-solving abilities in biology students and whether the academic level affects KPS results and problem-solving abilities. This research is an experimental study with a one-shot case study design. In this study, students carried out independent practicum outside the mini research-based laboratory. The research subjects involved students with different academic levels, namely students in semester 4 and semester 6 . The research data consisted of mini-research report scores, KPS scores, and problem-solving abilities. Data were analyzed using the Manova test and linear regression. Based on the results of the regression test, it shows that the miniresearch has a significant effect on Integrated KPS and problem-solving abilities. The results of the Manova test showed that there were differences in KPS and problemsolving abilities in terms of academic level, it was explained that students with the upper academic level (semester 6) mastered KPS and problem-solving abilities were higher than students at lower academic levels (semester 4). The average KPS level for students at the top academic level is 67.6 (High), and the level of problem-solving ability is 73.7 (High), while the average KPS level for students at the lower academic level is 52 (Low) and the level of problem-solving ability is 61 (Moderate). These results indicate that research mini-research has an effect on Integrated KPS and student problem-solving abilities, as well as the KPS level and problem-solving abilities at the upper academic level higher than the lower academic level. Thus mini-research learning contributes to facilitating Integrated KPS and biological problem-solving skills.
\end{abstract}

Keywords: Analysis; Integrated science process skills; Problem-solving ability; Mini research learning

\section{Introduction}

Constructivism learning theory explains the philosophy of learning which emphasizes that learning is not just memorizing, but constructing or building new knowledge and skills, through the facts they experience in their lives [11]. One of the constructivism learning models is mini research learning, mini research learning is learning that uses problems as a first step in collecting information and processing information. Through this learning, students are facilitated to design their own projects to be carried out, so that students can carry out exploration, interpretation, analysis, synthesis and evaluation. The results of the analysis of problems identified in the learning process in the Biology Education study program in general are that biology courses has been equipped with experiments, but most of them are only verification, not yet facilitating students to solve problems using the principles of scientific 
methods starting from formulating problems, compiling hypotheses, determining variables, designing and conducting experiments, processing data and presenting conclusions to answer problems. Students are not used to doing research to solve learning problems so this condition affects their problem solving skills and integrated science process skills.

It is deemed necessary for students to have problem solving skills, because this ability can help students make decisions that are right, careful, systematic, logical and consider various points of view. On the other hand, this lack of ability causes students to carry out various activities without knowing the purpose and reasons for doing them [22]. Solving problems is also a form of thinking. The ability to solve problems is not only related to the accuracy of the solutions obtained, but the ability shown since recognizing problems, finding alternative solutions, choosing one alternative as a solution, and evaluating the answers that have been obtained. Problem solving ability is considered the most complex intellectual function [15]. Meanwhile, according to [1] problem solving skills include thinking and reasoning skills, which also include metacognitive abilities and critical thinking. There are many steps from a person's approach to solving problems, depending on the level of difficulty of the problem, but the sequence is the creative steps that are usually done in problem solving.

Science process skills (KPS) are very important to use as a bridge in conveying knowledge / information to students or developing knowledge or information that students already have, so as to improve student learning outcomes. KPS involves skills such as cognitive, manual, and social [20]. [13] in her publication in The National Association for Research in Science Teaching (NARST) argues that KPS consists of 2 types, namely basic and integrated science process skills. Basic KPS consists of several indicators, namely observing, inferring, measuring, communicating, classifying, and predicting. This study does not measure basic KPS, but integrated KPS with indicators of formulating problems, creating hypotheses, identifying and controlling variables, making operational definitions, conducting experiments, collecting data, interpreting data, and making models.

The appropriate learning applied to teach the Phanerogamae Botany course in semester 4 and Endocrinology in semester 6 is mini research learning. Mini research is identical to one type of inquiry, namely free inquiry. Free inquiry is one level in inquiry learning that encourages students to identify a problem, find a solution to the problem through an experiment [23]. The main target of inquiry is how the involvement and interaction of students in the process of learning activities, so that students can actively participate in finding or connecting the knowledge obtained. Mini research activities can raise and even improve various student competencies. These competencies are not only in the form of cognitive, even affective and skills. One of the skills is scientific process skill either basic or integrated one.

Learn by getting students to solve problems where this type of learning can shape students to think scientifically and critically through problem solving activities. Students are required to be skilled in solving the problems given, with this problem it can increase the active role of students in finding their own answers to the problems given by optimizing their scientific process skills [14]. This is in accordance with mini research learning where students are faced with problems and must solve these problems scientifically so that in addition to being able to build understanding of the concept, students also train skills in problem solving and science process skills. The results of previous research show that mini research learning can facilitate and improve KPS where previously only basic KPS has increased to become integrated KPS [16]. This is in line with the results of research which show that the application of mini research learning can facilitate students to build their own concepts so that they can improve their mastery of the concept [ 9]. 


\section{Method}

The method used in this study is a pre-experimental research method with a one-shot case study design, in this study, there was no control group [4]. The research subjects, namely students in level 2 and level 3 were given treatment, namely mini research learning. Then at the end of the program, students are given a test related to the treatment given. In this study, there were 3 research variables, namely mini research learning as independent or independent variables (X). problem solving skills (Y1), integrated KPS (Y2) as the dependent or dependent variable. The instruments used are; Observation sheet to see the implementation of mini research, the performance assessment sheet is equipped with an assessment rubric to measure students' integrated science process skills when they perform a mini-set performance, and test questions are used to measure problem-solving skills.

Data analysis used prerequisite tests (normality and homogeneity) followed by hypothesis testing using one-way Manova (Multivariate Analysis of Variance) test with one independent variable and two dependent variables. In addition to Manova, a linear regression test was also carried out with the help of SPSS version 21 software at a significance level of $\alpha=0.05$ [2]. Data analysis used prerequisite tests (normality and homogeneity) followed by hypothesis testing using one-way Manova (Multivariate Analysis of Variance) test with one independent variable and two dependent variables. In addition to Manova, a linear regression test was also carried out with the help of SPSS version 21 software at a significance level of $\alpha=0.05$ [2]. Data analysis used prerequisite tests (normality and homogeneity) followed by hypothesis testing using one-way Manova (Multivariate Analysis of Variance) test with one independent variable and two dependent variables. In addition to Manova, a linear regression test was also carried out with the help of SPSS version 21 software at a significance level of $\alpha=0.05$ [2].

\section{Result and Discussion}

This study aims to analyze the effect of mini research learning on problem solving abilities (KPM) and Integrated KPS in Biology Education students represented by students at level 2 (lower level) and level 3 (upper level) as well as to analyze the differences between KPM and Integrated KPS at lower and higher level students on.

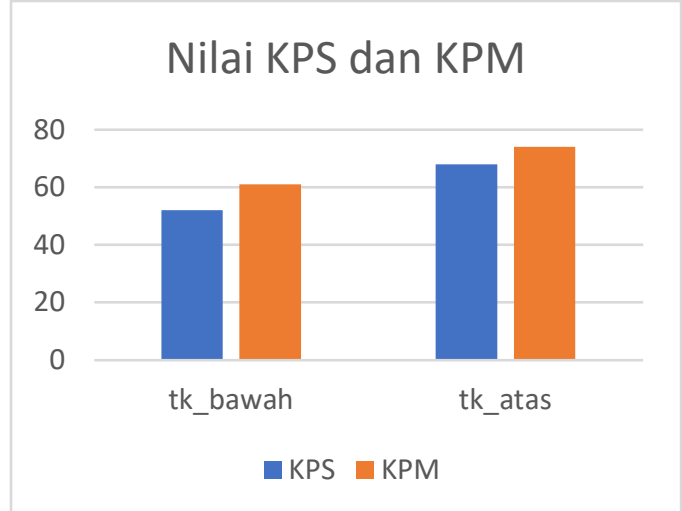

Fig 1. Comparison of KPS and KPM values 
Figure 1 explains that the average KPM value obtained by level 2 students (lower level) is 61 (moderate level) and students level 3 (upper level) is 74 (high level). While the average KPS score obtained by students in level 2(lower level) is 52 (medium level) and students in level 3 (upper level) is 68 (high level). So it can be concluded that the average KPM and KPS scores for upper-level students are higher than those for lower-level students. This result is reinforced by the Manova test which shows that the academic level significantly affects the problem-solving ability and Integrated KPS through mini-research learning or there are differences in problem-solving abilities and Integrated KPS for lower-level students and upper-level students.

\begin{tabular}{|c|c|c|c|c|c|c|c|}
\hline Source & $\begin{array}{l}\text { Dependent } \\
\text { Variable }\end{array}$ & $\begin{array}{c}\text { Type III } \\
\text { Sum of } \\
\text { Squares }\end{array}$ & df & $\begin{array}{l}\text { Mean } \\
\text { Square }\end{array}$ & $\mathbf{F}$ & Sig. & $\begin{array}{c}\text { Partial Eta } \\
\text { Squared }\end{array}$ \\
\hline \multirow{2}{*}{$\begin{array}{l}\text { Corrected } \\
\text { Model }\end{array}$} & KPS & $2217.330 \mathrm{a}$ & 1 & 2217,330 & 13,124 & .001 & .262 \\
\hline & Problem solving & $1507.385 b$ & 1 & 1507,385 & 8,535 & .006 & .187 \\
\hline \multirow[t]{2}{*}{ Intercept } & KPS & 138566,560 & 1 & 138566,560 & 820,179 & .000 & .957 \\
\hline & Problem solving & 174752,308 & 1 & 174752,308 & 989,428 & .000 & .964 \\
\hline \multirow{2}{*}{$\begin{array}{l}\text { academic } \\
\text { level }\end{array}$} & KPS & 2217,330 & 1 & 2217,330 & 13,124 & .001 & .262 \\
\hline & Problem solving & 1507,385 & 1 & 1507,385 & 8,535 & .006 & .187 \\
\hline
\end{tabular}

From the results of Table 1. Manova test results, the data is said to be significant if the Sig. $<0.05$. From the data table 2 shows the sig value $<0.05$, so that the conclusion and answer to the hypothesis is that the academic level significantly affects KPM and KPS, which means that $\mathrm{H} 0$ is rejected or $\mathrm{H} 1$ is accepted. After mini research learning, upper academic level students have higher problem-solving skills and KPS scores than lower academic level students. This is in line with the theory which explains that students who have different academic levels are then given the same learning, so the results of their learning will differ according to their level of academic ability [25].

From these results, it is explained that upper level students have been trained to do practicum which is not only a verification of theory but practicum that is identical to inquiry where students formulate problems, design experiments to interpret data independently. Meanwhile, lower level students are used to doing verification practicum and are still practicing to do practicum independently. Learning using Inquiry combined with Vee Diagram can improve KPS especially upper academic level students whose result are higher than lower academic level students [6]. So that upper-level students are more focused and skilled in doing mini-research practicum, in terms of mini research-reports of upper-level students are also more systematic and focused on solving learning problems scientifically. It's different with the results of mini research- report of lower-level students that are still not focused when determining the problem formula as it effects on the stage and the next step.

Table 2. Model Summary

\begin{tabular}{ccccc}
\hline \multicolumn{5}{c}{ Table 2. Model Summary } \\
model & $\mathrm{R}$ & R Square & $\begin{array}{c}\text { Adjusted R } \\
\text { Square }\end{array}$ & $\begin{array}{c}\text { Std. Error of the } \\
\text { Estimate }\end{array}$ \\
\hline 1 & $.786 \mathrm{a}$ & .617 & .607 & 9,133 \\
2 & $.698 \mathrm{a}$ & .487 & .473 & 10,833 \\
\multicolumn{5}{c}{ a. Predictors: (Constant), new mini research } \\
\hline
\end{tabular}

Based on Table 2, it is explained in model 1 that the value of the correlation / relationship (R) is 0.786 and the percentage of the influence of the independent variable $(\mathrm{X})$ mini research on the dependent variable (Y1) The problem solving ability is called the coefficient of determination which is the result of squaring $\mathrm{R}$ From this output, the coefficient of 
determination (R2) is 0.617 , which implies that the effect of the independent variable (miniriset) on the dependent variable (problem solving ability) is $61.7 \%$. Whereas in model 2 explains the value of the correlation / relationship (R) which is equal to 0.698 and explains the percentage of the influence of the independent variable $(\mathrm{X})$ mini research on the dependent variable (Y2) KPS which is called the coefficient of determination which is the result of R squaring. From that output obtained coefficient of determination (R2) is 0,487 , which implies that the effect of the independent variable (miniriset) on the dependent variable (problem solving ability) (KPS) is $48,7 \%$.

\begin{tabular}{llr|r|r|r|r}
\multicolumn{7}{c}{ Table 3 ANOVAa } \\
Model & & Sum of Squares & Df & Mean Square & \multicolumn{1}{c}{ F } & \multicolumn{1}{c}{ Sig. } \\
\hline 1 & Regression & 4962,666 & 1 & 4962,666 & 59,623 & $.000 \mathrm{~b}$ \\
& Residual & 3079,642 & 37 & 83,234 & & \\
& Total & 8042,308 & 38 & & & \\
\hline
\end{tabular}

a. Dependent Variable: KPM

b. Predictors: (Constant), new mini research

In table 3 this anova is to explain whether there is a real (significant) effect of variable $\mathrm{X}$ (miniriset) on Variable Y (KPM). From this output, it can be seen that F count $=59.6$ with a significance level of $0.000<0.05$, so there is a significant effect of the miniriset variable on problem solving ability. The results of the hypothesis test show that there is a significant effect of mini-research learning on the problem-solving ability of lower and upper-level biology education students who take the Botany Phanerogamae and Endocrinology courses. Mini research learning has an effect on the problem-solving abilities of students both lower and upper level students, where The category of problem solving ability of lower level students is medium and upper level students are high.

These results indicate that mini-research learning through independent practicum carried out by students facilitates and improves students' problem solving abilities. The main focus in learning should be problem solving learning, because this is a very important skill for the next student life [7]. Thinking learning with everyday life will make it easier for students to understand concepts and be able to apply this learning in life so as to improve problem-solving abilities. Mini research learning that is identical to inquiry can bring up research context that is very supportive for the development of cognitive skills, because this learning puts forward learning problems [8].

During the process of mini research learning lecturers act as a facilitator and guide college student in planning and conducting mini research. College student independently design learning through a mini research project that will be implemented. The ability of college student to analyze comes up with train college student to research and solve problem that happened [10]. The process of mini learning research according to [5] is able to improve analysis skills as a basis for critical thinking skills. This is because in the mini-research learning process, students try on their own to solve a problem that occurs around them with real experiences. The strategy used by students to solve problems is IDEAL problem solving where the steps make it easier for students to solve learning problems. IDEAL is a problemsolving strategy that can improve thinking skills and improve skills in the problem-solving process. IDEAL strategies are designed to help identify problems and understand problemsolving steps [24]. 
Table 4. ANOVAa

\begin{tabular}{llr|r|r|r|r} 
Model & & Sum of Squares & Df & Mean Square & F & Sig. \\
\hline 1 & Regression & 4126,124 & 1 & 4126,124 & 35,159 & $.000 \mathrm{~b}$ \\
& Residual & 4342,235 & 37 & 117,358 & & \\
& Total & 8468,359 & 38 & & & \\
\hline
\end{tabular}

a. Dependent Variable: KPS

b. Predictors: (Constant), new mini research.

In table 4. this anova is to explain whether there is a real (significant) effect of variable $\mathrm{X}$ (miniriset) on Variable Y (KPS). From this output, it can be seen that F count $=35.159$ with a significance level of $0.000<0.05$, so there is a significant effect of the miniriset variable on KPS. The results of the hypothesis test show that there is a significant effect of mini-research learning on Integrated Science Process Skills (KPS) for lower and upper-level biology education students who take Phanerogamae Botany and Endocrinology courses. Integrated KPS is assessed using a performance assessment that contains the KPS indicators that have been determined in this study. The assessment is carried out during the mini-research-based practicum process and student lab reports. Through this mini research study allows students to explore their own interests. Mini learning effective research for students can focus on developing their experiments, practicing integrated KPS such as searching for literature and formulating hypotheses [19].

Mini research learning is identical to one type of inquiry, namely free inquiry. Free inquiry is one level in inquiry learning that encourages students to identify a problem, find a solution to the problem through an experiment [23]. The main target of inquiry is how the students are involved and interacted in the learning process, so that students can actively participate in finding or connecting the knowledge obtained [2]. Mini learning research on practicum Endocrinology and Botany Phanerogamae identic with free inquiry where students independently determine the formulation of the problem, hypothesis, determine the variables to be studied, design experiments, analyze and interpret the experimental data. Students independently carry out investigations based on existing problems in accordance with predetermined themes, while the lecturer only accompanies and facilitates the inquiry-based practicum process.

This mini research activity is an independent practicum activity that provides an opportunity for students to prove theories and discover theories. Many concepts and principles can be formed in the minds of students through a generalization process from observed facts (observations), making hypotheses to proving hypotheses which are KPS competencies [21]. Basically, KPS is very important to be trained in learning, because KPS is an ability that scientists use while working and also a competency needed when solving scientific problems [17]. Research skills help students to critically investigate problems, produce, and evaluate relevant data, test ideas, theories, and hypotheses, and successfully guide the way for them to navigate the sea of information that characterizes the era information [12].

\section{Conclusion}

The conclusion of this research is that based on statistical tests there is an effect of mini research learning on the problem solving ability of biology education students, there is an effect of mini research learning on Integrated KPS biology education students. Where biology education students consist of lower and upper level students, and the results of statistical tests show that there is a significant difference between problem-solving abilities and Integrated 
KPS students at lower and upper levels. The results of the problem-solving ability and Integrated KPS for upper-level students were higher in terms of comprehension than lowerlevel students.

\section{References}

[1] Barrows, H.S. (1996). Problem-based learning in medicine and beyond: A brief overview. New Directions for Teaching and Learning, 68, 3-12. doi: 10.1002/t1.37219966804

[2] Brunner, J, 1978, The Process of Educational Technology, Cambridge : Harvard University

[3] Cornelius, T. (2010). Step by Step SPSS 18 Analisis Data Statistik. Yogyakarta: Andi.

[4] Cresswell, J.W. (2017). Research Design Pendekatan metode Kualitatif, Kuantitatif, dan Campuran Edisi 4. Yogyakarta: Pustaka Pelajar

[5] Daulae, A. H., Lazuardi \& M. A. Napitupulu. 2017. Kajian Penerapan Tugas Mini Riset Terhadap Hasil Belajar Mahasiswa Materi Keanekaragaman Hayati. Jurnal Pelita Pendidikan 5 (4)

[6] Handayani, Setiawati, 2015, Efektivitas Pembelajaran Biokimia Dengan Model Pembelajaran Inkuiri Dipadu Vee Diagram Terhadap Keterampilan Proses Sains dan Pemahaman Konsep Pada Mahasiswa Dengan Kemampuan Akademik Atas dan Bawah, Quagga: Jurnal Pendidikan dan Biologi,Vol.7(1)

[7] Jonassen, D. H. 2000. Toward a Design Theory of Problem Solving. EducationalTechnology Research and Development 48 (4): 63-85. New York: Springer.

[8] Junaedi, E, 2015, Model Latihan Inkuiri (Inquiry Training Model) ; Pembelajaran Bermakna Yang Melatih Keterampilan-keterampilan Penelitian, Quagga: Jurnal Pendidikan dan Biologi,Vol.7(1)

[9] Leksono, S,M, 2016, Pengaruh Pembelajaran Mini Riset Berbasis Kearifan Lokal Terhadap Penguasaan Materi Biologi Konservasi, Proceeding Biology Education Conference (ISSN: 25285742), Vol 13(1) 2016

[10] Kusnadi, et al, (2012). Analisis Kemunculan Keterampilan Spesifik Laboratorium Mikrobiologi Melalui Pembelajaran Mikrobiologi Berbasis Proyek Inkuiri Mini Riset Mahasiswa Biologi “ Jurnal Pengajaran MIPA" 17 (1)

[11] Muslich, M. (2008). KTSP Pembelajaran Berbasis Kompetensi Dan Kontekstual. Jakarta: PT Bumi Aksara.

[12] Nurlaelah, et al, 2020, Student's Research Skills in Middle School of Kuningan District, Journal of Physics: Conference series, Vol 1521, No.1, May 2020

[13] Padilla, M.J. (1990). The Science Process Skills. National Association for Research in Science Teaching, No. 9004. Retrieved from https://www.narst.org/publications/research/skill.cfm

[14] Pait, M.I, 2011, Pengaruh Model Pembelajaran Problem Solving dan Penalaran Formal Terhadap Prestasi Belajar Matematika Siswa Menengah Pertama. Artikel. Universitas Pendidikan Ganesha Raehanah

[15] Peng, C.N. 2004. Successful Problem-Based Learning for Primary and Secondary Classrooms. Singapore: Federal Publications.

[16] Permari, 2016, Pengaruh Mini Riset Terhadap Keterampilan Proses Sains Terintegrasi Siswa Pada Materi Pencemaran Lingkungan, Proceeding Biology Education Confrence Vol.13, No.1

[17] Peter N. Brotherton \& Peter F. W. Preece (2006) Science Process Skills: their nature and interrelationships, Research in Science \& Technological Education, 13:1, 5-11, DOI: 10.1080/0263514950130101

[18] Pramana, B. 2006. Problem Solving. (Online). (http://sarengbudi.web.id/-wpcontent/uploads/problem-solving.doc, diakses 26 Desember 2006).

[19] Russell Souchek \& Marjorie Meier (1997) Teaching Information Literacy and Scientific Process Skills: An Integrated Approach, College Teaching, 45:4, 128-131, DOI: $10.1080 / 87567559709596213$

[20] Rustaman, N.Y., et al. (2003). Strategi Belajar Mengajar Biologi. Bandung: Jurusan Pendidikan Biologi FPMIPA UPI. 
[21] Setiawati, I., Handayani, H. (2018). Pengembangan Panduan Praktikum Kimia Dasar Berbasis Keterampilan Proses Sains dan Asesmen Autentik Di Laboratorium. Quagga: Jurnal Pendidikan dan Biologi, 10(1), 63-70. doi: 10.25134/quagga.v10i01.873.

[22] Takwim, Bagus. 2006. Mengajar Anak Berpikir Kritis. (Online). (www.kompas.-com/kesehatan/news/0605/05/093521.htm, diakses 26 November 2006)

[23] Wenning, C.J. (2005). Levels of Inquiry: Hierarchies ofPedagogical Practices and Inquiry Process. Journal of Physiscs Teacher Education Online, 2, (3), 3-12. Retrieved from http://www2.phy.ilstu.edu/pte/publications/levels of i nquiry.pdf

[24] Widiantie, R, Lilis, L, (2017). Upaya Meningkatkan Keterampilan Pemecahan Masalah Dengan Strategi IDEAL Melalui Pembelajaran Berbasis Masalah Pada Materi kelenjar Endokrin. Quagga: Jurnal Pendidikan dan Biologi 9 (01)

[25] Wulanningsih, S, Prayitno, B, \& Probosar, R.(2012). Pengaruh Model Pebelajaran Inkuiri Terbimbing Terhadap Keterampilan Proses Sains Ditinjau dari Kemampuan Akademik SMA Negeri 5 Surakarta. Jurnal Pendidikan Biologi, 4(2), 33-43 